Prepared in cooperation with U.S. Joint Fire Science Program and National Interagency Fire Center, Bureau of Land Management, Great Northern Landscape Conservation, and Western Association of Fish and Wildlife Agencies

\title{
Restoration Handbook for Sagebrush Steppe Ecosystems with Emphasis on Greater Sage-Grouse Habitat- Part 2. Landscape Level Restoration Decisions
}

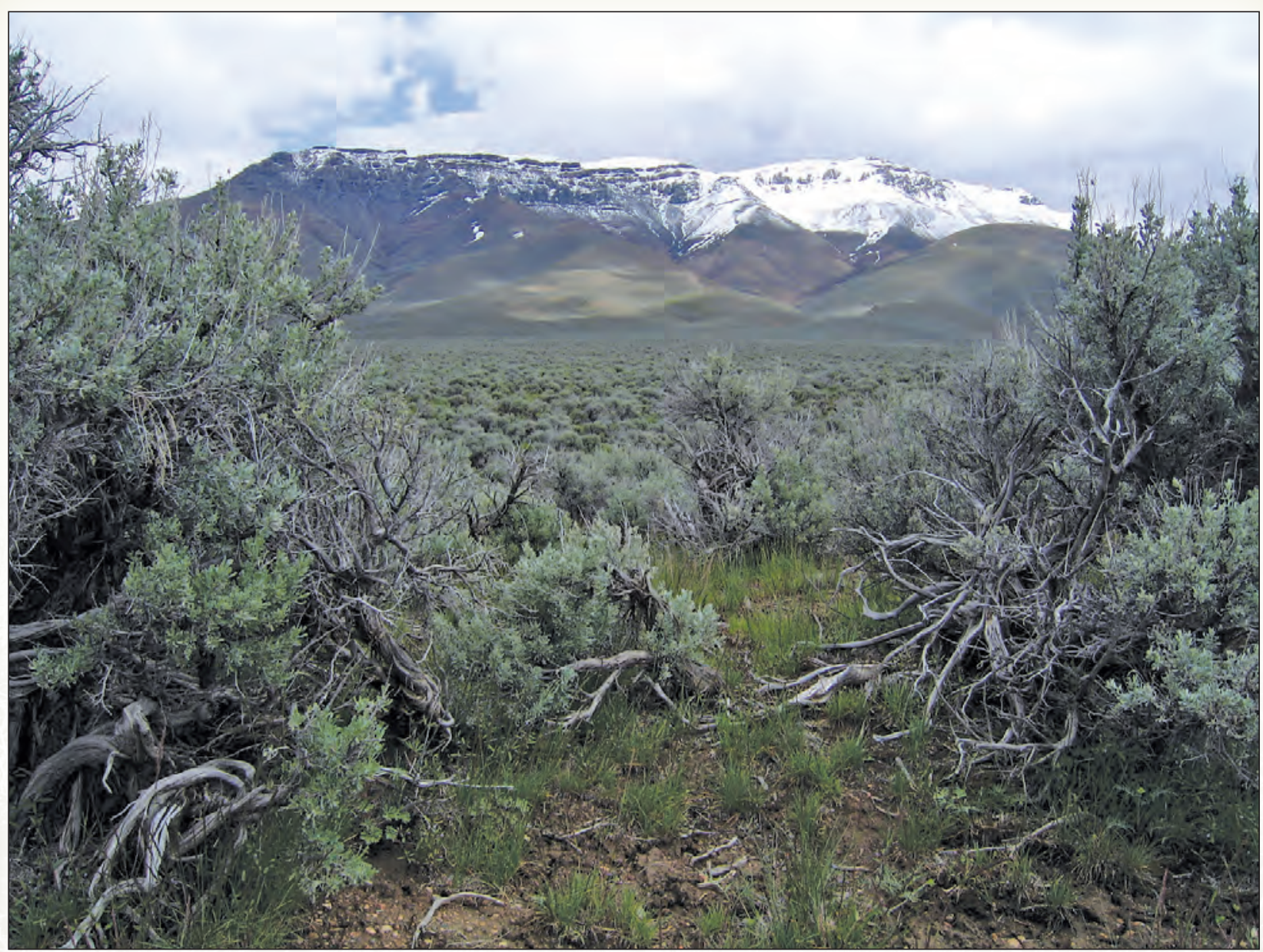

Circular 1418

U.S. Department of the Interior

U.S. Geological Survey 
Cover: Photograph showing Wyoming big sagebrush community near Winnemucca, Nevada. (Photograph by David Pyke, U.S. Geological Survey, 2005.) 


\section{Restoration Handbook for Sagebrush Steppe Ecosystems with Emphasis on Greater Sage-Grouse Habitat-Part 2. Landscape Level Restoration Decisions}

By David A. Pyke, Steven T. Knick, Jeanne C. Chambers, Mike Pellant, Richard F. Miller, Jeffrey L. Beck, Paul S. Doescher, Eugene W. Schupp, Bruce A. Roundy, Mark Brunson, and James D. Mclver

Prepared in cooperation with U.S. Joint Fire Science Program and National Interagency Fire Center, Bureau of Land Management, Great Northern Landscape Conservation, and Western Association of Fish and Wildlife Agencies

Circular 1418 


\title{
U.S. Department of the Interior SALLY JEWELL, Secretary
}

\section{U.S. Geological Survey Suzette M. Kimball, Acting Director}

\author{
U.S. Geological Survey, Reston, Virginia: 2015
}

For more information on the USGS - the Federal source for science about the Earth, its natural and living resources, natural hazards, and the environment-visit http://www.usgs.gov or call 1-888-ASK-USGS.

For an overview of USGS information products, including maps, imagery, and publications, visit http://www.usgs.gov/pubprod/.

Any use of trade, firm, or product names is for descriptive purposes only and does not imply endorsement by the U.S. Government.

Although this information product, for the most part, is in the public domain, it also may contain copyrighted materials as noted in the text. Permission to reproduce copyrighted items must be secured from the copyright owner.

Suggested citation:

Pyke, D.A., Knick, S.T., Chambers, J.C., Pellant, M., Miller, R.F., Beck, J.L., Doescher, P.S., Schupp, E.W., Roundy, B.A., Brunson, M., and Mclver, J.D., 2015, Restoration handbook for sagebrush steppe ecosystems with emphasis on greater sage-grouse habitat—Part 2. Landscape level restoration decisions: U.S. Geological Survey Circular 1418, 21 p., http://dx.doi.org/10.3133/cir1418.

\section{Library of Congress Cataloging-in-Publication Data}

Names: Pyke, David A. | Joint Fire Science Program (U.S.)

Title: Restoration handbook for sagebrush steppe ecosystems with emphasis on greater sage-grouse habitat / prepared in cooperation with U.S. Joint Fire Science Program and National Interagency Fire Center, Bureau of Land Management, Great Northern Landscape Conservation, and Western Association of Fish and Wildlife Agencies.

Description: Reston, Virginia : U.S. Geological Survey, 2015- | Series:

Circular ; 1416, 1418 | Includes bibliographical references and index. Identifiers: LCCN 2015035308| ISBN 9781411339682 (pt. 1 : pbk. : alk. paper) | ISBN 9781411339972 (pt. 2 : pbk. : alk. paper)

Subjects: LCSH: Sagebrush steppe ecology--United States. | Steppe restoration--United States. | Sage grouse--Habitat--Conservation--United States.

Classification: LCC QH104 .R467 2015 | DDC 333.74/153--dc23

LC record available at http://lccn.loc.gov/2015035308 


\section{Preface}

"So naturalists observe, a flea

Has smaller fleas that on him prey;

And these have smaller fleas to bite 'em,

And so proceeds ad infinitum."

From Jonathan Swift, On Poetry: A Rhapsody, 1733

Ecosystems are scale dependent much like Jonathan Swift's fleas. Restoration of sagebrush steppe ecosystems requires more than identifying a degraded site and replanting native vegetation in appropriate densities. Ecosystems include the entire environment of living and nonliving parts and their interactions. Disturbances, such as wildfires and land uses, may alter ecosystems and influence habitat quality of species at scales varying from shrubs to sites to landscapes and over time from an immediate effect to decades of influence. Although the implementation of restoration is conducted at the site or local level, where we place restoration projects may influence whether benefits from that project can be expressed at a landscape level. This is especially true for species whose home range extends beyond the boundaries of that individual restoration site.

We have developed this landscape restoration decision tool within this context of sites functioning within the larger regional mosaic. The tool relies on the user's understanding of space and time relationships in sagebrush steppe ecosystems and habitat needs for animals that in some cases exclusively use sagebrush-dominated communities for their survival and reproduction. These concepts were reviewed in Part 1 of the handbook on restoration of sagebrush (Artemisia spp.) steppe ecosystems (Pyke and others, 2015) and are intended as a reference for the landscape restoration decision tool in this part of the handbook. We encourage users to read and understand these concepts before applying this decision support tool. 

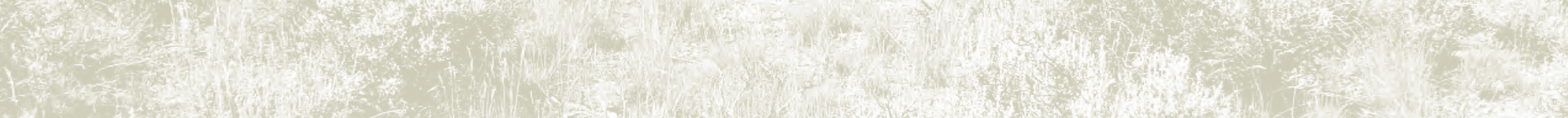


\section{Contents}

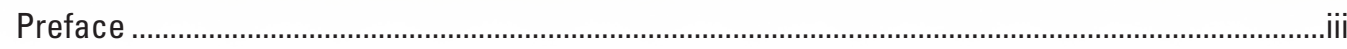

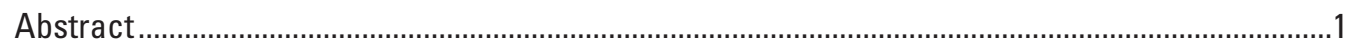

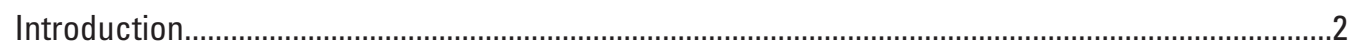

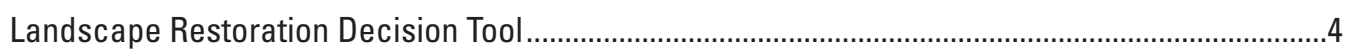

Section 1. Am I Dealing with Landscape-Related Restoration Issues? ...................................4

Section 2. What Are Regional or Landscape Objectives for Restoration? ..............................8

Section 3. Where Are Priority Landscapes and Sites within Landscapes for Restoration? .......................................................................................................11

Section 4. Prioritize Landscapes Using a Resilience and Resistance Matrix ..........................17

Section 5. Monitor and Report Information on Your Measurable Landscape Objectives ......19

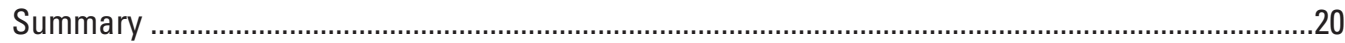

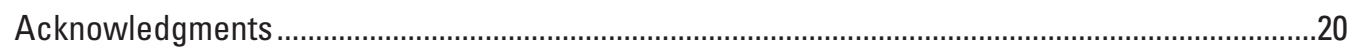

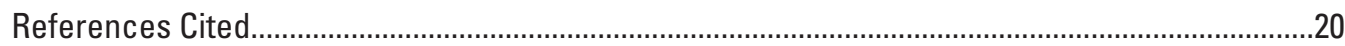

\section{Figures}

1. Map showing greater sage-grouse Priority Areas for Conservation (PACs) within the current range of greater sage-grouse in the Western United States and

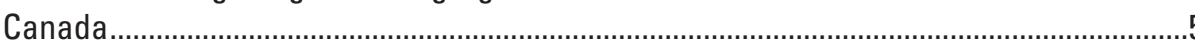

2. Map showing soil temperature and moisture regimes that characterize the greater sage-grouse management zones ...................................................................

3. Maps showing three hierarchical scales in a decision process for identifying restoration actions ....................................................................................................

4. Map showing estimates of breeding bird density of the greater sage-grouse ...............13

5. Map showing landscape cover of sagebrush within each of the selected categories $(<25,25-65,>65$ percent $)$ for the greater sage-grouse management zones.

\section{Tables}

1. Major sagebrush ecological types in California, Idaho, Nevada, Oregon, Utah, and Washington

2. Sage-grouse habitat matrix based on resilience and resistance concepts, and the proportional cover of the landscape dominated by sagebrush 


\section{Conversion Factors}

Inch/Pound to International System of Units

\begin{tabular}{|c|c|c|}
\hline Multiply & By & To obtain \\
\hline \multicolumn{3}{|c|}{ Length } \\
\hline inch (in.) & 2.54 & centimeter (cm) \\
\hline inch (in.) & 25.4 & millimeter (mm) \\
\hline mile (mi) & 1.609 & kilometer (km) \\
\hline
\end{tabular}

International System of Units to Inch/Pound

\begin{tabular}{lcc}
\hline \multicolumn{1}{c}{ Multiply } & By & To obtain \\
\hline & Length & \\
\hline centimeter $(\mathrm{cm})$ & 0.3937 & inch (in.) \\
kilometer $(\mathrm{km})$ & 0.6214 & mile (mi) \\
\hline \multicolumn{3}{c}{ Area } \\
\hline square kilometer $\left(\mathrm{km}^{2}\right)$ & 0.3861 & square mile $\left(\mathrm{mi}^{2}\right)$ \\
\hline
\end{tabular}

Temperature in degrees Celsius $\left({ }^{\circ} \mathrm{C}\right)$ may be converted to degrees Fahrenheit $\left({ }^{\circ} \mathrm{F}\right)$ as ${ }^{\circ} \mathrm{F}=\left(1.8 \times{ }^{\circ} \mathrm{C}\right)+32$.

Temperature in degrees Fahrenheit $\left({ }^{\circ} \mathrm{F}\right)$ may be converted to degrees Celsius $\left({ }^{\circ} \mathrm{C}\right)$ as ${ }^{\circ} \mathrm{C}=\left({ }^{\circ} \mathrm{F}-32\right) / 1.8$.

\section{Datum}

Horizontal coordinate information is referenced to the North American Datum of 1983 (NAD 83). 


\title{
Restoration Handbook for Sagebrush Steppe Ecosystems with Emphasis on Greater Sage-Grouse Habitat- Part 2. Landscape Level Restoration Decisions
}

\author{
By David A. Pyke', Steven T. Knick', Jeanne C. Chambers², Mike Pellant ${ }^{3}$, Richard F. Miller ${ }^{4}$, Jeffrey L. Beck ${ }^{5}$, \\ Paul S. Doescher ${ }^{6}$, Eugene W. Schupp ${ }^{7}$, Bruce A. Roundy ${ }^{8}$, Mark Brunson ${ }^{9}$, and James D. Mclver ${ }^{10}$
}

\section{Abstract}

Sagebrush steppe ecosystems in the United States currently (2015) occur on only about one-half of their historical land area because of changes in land use, urban growth, and degradation of land, including invasions of non-native plants. The existence of many animal species depends on the existence of sagebrush steppe habitat. The greater sage-grouse (Centrocercus urophasianus) is a landscape-dependent bird that requires intact habitat and combinations of sagebrush and perennial grasses to exist. In addition, other sagebrush-obligate animals also have similar requirements and restoration of landscapes for greater sage-grouse also will benefit these animals. Once sagebrush lands are degraded, they may require restoration actions to make those lands viable habitat for supporting sagebrush-obligate animals.

Land managers do not have resources to restore all locations because of the extent of the restoration need and because some land uses are not likely to change, therefore, restoration decisions made at the landscape to regional scale may improve the effectiveness of restoration to achieve landscape and local restoration objectives. We present a landscape restoration decision tool intended to assist decision makers in determining landscape objectives, to identify and prioritize landscape areas where sites for priority restoration projects might be located, and to aid in ultimately selecting restoration sites guided by criteria used to define the landscape objectives. The landscape restoration decision tool is structured in five sections that should be addressed sequentially. Each section has a primary question or statement followed by related questions and statements to assist the user in addressing the primary question or statement. This handbook will guide decision makers through the important process steps of identifying appropriate questions, gathering appropriate data, developing landscape objectives, and prioritizing landscape patches where potential sites for restoration projects may be located. Once potential sites are selected, land managers can move to the site-specific decision tool to guide restoration decisions at the site level.

\footnotetext{
${ }^{1}$ U.S. Geological Survey, Forest and Rangeland Ecosystem Science Center.

${ }^{2}$ U.S. Forest Service, Rocky Mountain Research Station.

${ }^{3}$ Bureau of Land Management.

${ }^{4}$ Eastern Oregon Agricultural Research Center, Oregon State University, Corvallis.

${ }^{5}$ Department of Ecosystem Science and Management, University of Wyoming, Laramie.

${ }^{6}$ Department of Forest Ecosystems and Society, Oregon State University, Corvallis.

${ }^{7}$ Department of Wildland Resources and the Ecology Center, Utah State University, Logan.

${ }^{8}$ Department of Plant and Wildlife Sciences, Brigham Young University, Provo.

${ }^{9}$ Department of Environment and Society and the Ecology Center, Utah State University, Logan.

${ }^{10}$ Eastern Oregon Agricultural Research Center, Oregon State University, Union.
} 


\section{Introduction}

Large parts of sagebrush (Artemisia sp.) steppe ecosystems have been replaced by crops or cities, fragmented, converted to invasive plants, or otherwise degraded so that the ecosystem now ranks as one of the most threatened in North America (Noss and others, 1995). This degradation ranges from specific sites that lack characteristic vegetation communities to entire landscapes of sagebrush steppe altered through wildfire or land uses such as farms, roads, energy developments, and infrastructure to transport power, oil, or natural gas. Restoration provides a mechanism to improve the plant structure and function at sites and halt further degradation. By strategically selecting landscape patches and sites within these patches, restoration also can improve landscape functions by decreasing habitat fragmentation, by providing the mosaic of habitat types required by wildlife, or by facilitating movement through corridors connecting intact sagebrush systems.

Many sagebrush-dependent wildlife species have been affected by habitat loss and change. For example, pygmy rabbits (Brachylagus idahoensis) have small home ranges and are dependent not only on intact sagebrushdominated plant communities, but also on deep soils with certain textures that support burrow construction. Identifying locations with appropriate soil textures near existing populations and restoring habitat in those locations are more likely to benefit pygmy rabbit populations than a similar restoration project established in an isolated location away from any pygmy rabbits or than another project adjacent to existing pygmy rabbits but in a location unable to support burrow construction. Alternatively, wildlife species with home ranges larger than the size of a typical restoration project or with seasonal habitat requirements may require a wider range of ecosystem characteristics across much broader areas to meet habitat needs and to maintain viable populations. Greater sage-grouse (Centrocercus urophasianus; hereinafter sage-grouse) fit this latter category. Both species in our example require specific landscape considerations when restoring habitat to achieve the greatest benefit.
Landscapes are a relative term but generally represent broad geographical areas that contain a mosaic of habitat patches that differ in environmental characteristics. Landscape objectives for restoration generally will exceed boundaries of any individual land management unit or project and will reflect the perspective (for example, national, regional, or local) from which objectives are designed. The spatial scale of lands that managers oversee or administer relate to their perspectives and may dictate the level of decisions important to them. On a larger regional or national level, a lender, grantor, or supervisory manager may need to evaluate and select restoration projects to implement from a large number of proposals. These managers may decide to fund projects that meet larger scale (landscape) objectives and have the greatest likelihood of success for not only the site's restoration goals, but for achieving landscape and regional goals as well. Individual landowners may evaluate potential restoration areas within their ownership to meet their own objectives given the management and objectives of their neighbor's lands. They evaluate required restoration based on the risk of success/failure when deciding to invest in a site-specific restoration project and whether cooperation with surrounding landowners would be necessary to achieve or contribute to the landscape objective.

Managers do not have resources to restore all lands because of the extent of the restoration need. In addition, some land uses that have changed these ecosystems will necessarily continue because they are economically or socially important (e.g., farming, mining, and energy development). Of those lands considered for restoration, some may have a higher importance because they possess environmental attributes amenable for successful restoration or because they have greater benefit to wildlife or the surrounding landscape. Thus, well-formulated decisions regarding placement of restoration projects within this landscape matrix of sagebrush steppe patches are necessary to gain the greatest benefit for sagebrush steppe ecosystems. By focusing restoration in these priority areas, managers can maximize efforts that enhance goals of a functioning landscape rather than merely creating a checkerboard of projects that might be successful in restoring sagebrush steppe plant communities, but unsuccessful in attaining landscape goals or in benefiting wildlife species. In essence, it is a triage approach. 
We present a landscape restoration decision tool intended to assist decision makers in determining landscape objectives, to identify and prioritize landscape areas where restoration projects might be located, and to aid in ultimately selecting restoration sites within a landscape guided by criteria used to define the landscape objectives. Restoration objectives that focus only on restoring plant communities and overlook habitat requirements of a targeted wildlife species for which the action was intended may not be sufficient to lead to a successful restoration project. If restoration is intended to support habitat needs of specific wildlife, then size of restoration project relative to the species' home range, types of plants needed, and placement of the project (relative to existing habitat, land uses, or current populations) become important. The process of identifying priority restoration locations also is critical for managers who wish to gain the greatest benefit in meeting wildlife population objectives with their limited resources. Not all restoration projects need to incorporate a landscape restoration decision tool, but restoration projects intended to improve habitat for landscape species, such as sage-grouse, are more likely to meet their objectives if this tool is used to guide restoration decisions.
The landscape restoration decision tool is structured in five sections that should be addressed sequentially. Each section has a primary question or statement followed by related questions and statements to assist the user in addressing the primary question or statement. Sage-grouse and its requirement for broad expanses of sagebrush habitat will be used as an example of landscape restoration throughout this handbook, but we emphasize that the process could be modified and used for other landscape-related restoration issues. The greater sagegrouse is a real-world example of a landscape species of conservation concern across its range where commitments to restore habitat contributed to the decision not to list it as a threatened or endangered species at this time (U.S. Fish and Wildlife Service, 2015) Habitat restoration at sites and across landscapes is viewed as a critical element for maintaining and increasing sage-grouse populations. This handbook will assist decision makers through the important process steps of identifying appropriate questions, gathering appropriate data, developing landscape objectives, and prioritizing locations. Once potential sites are selected, project managers can move to the site-specific decision tool to guide restoration decisions at the site level.

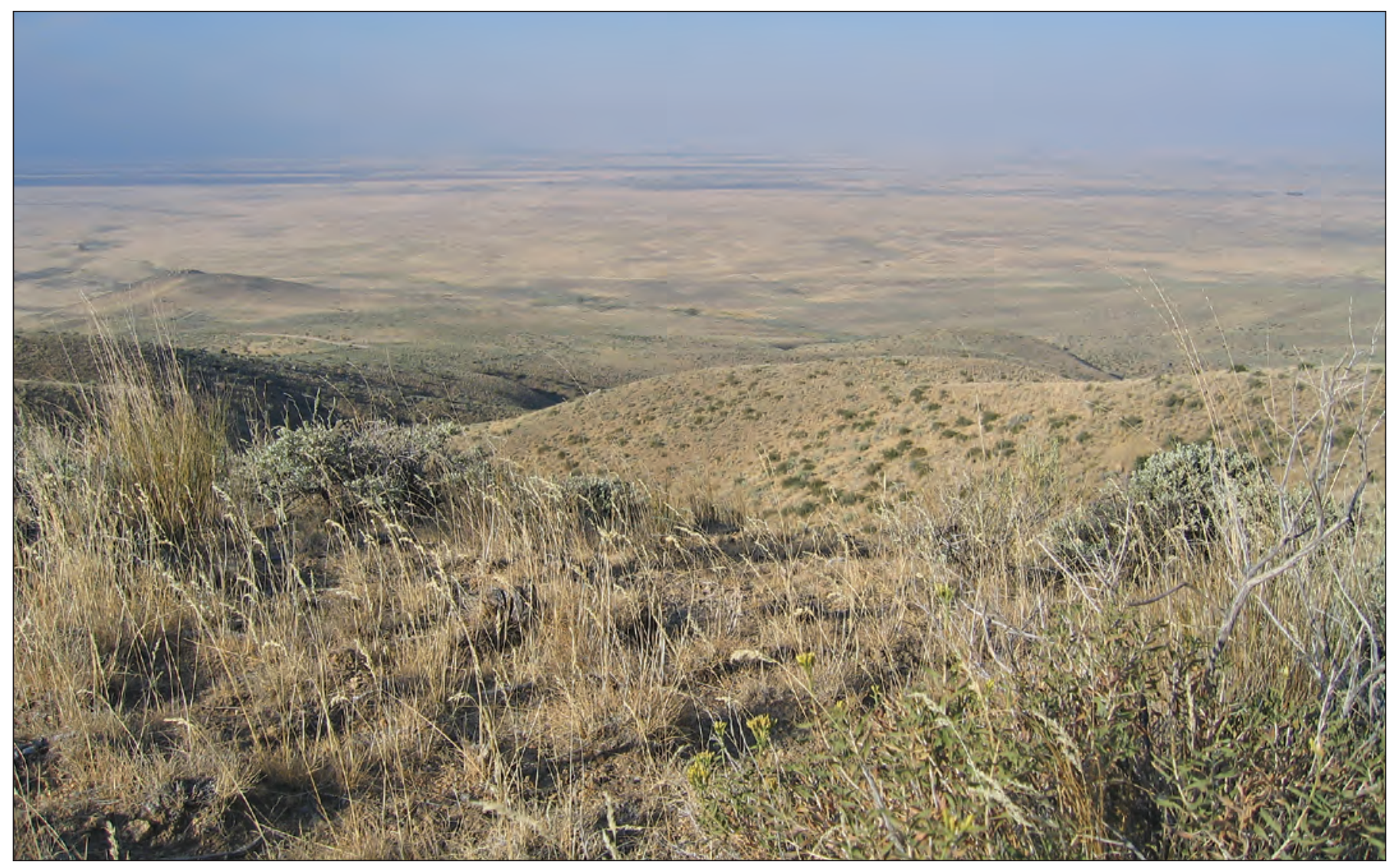

A Wyoming big sagebrush (Artemisia tridentata subsp. wyomingensis) stand dominated by native perennial grasses and forbs near Mountain Home, Idaho, looking from the foothills toward the Snake River Plain. Photograph by David Pyke, U.S. Geological Survey, August 23, 2006. 


\section{Landscape Restoration Decision Tool}

\section{Section 1. Am I Dealing with Landscape-Related Restoration Issues?}

If you answer "yes” to any of the following questions, then you likely have landscape-related restoration issues. This landscape decision tool may instruct where restoration success might likely occur and where restoration may benefit landscape objectives.

- Are you attempting to restore habitat for animal populations that depend on a mix of different habitat patches to meet seasonal requirements?

$\circ$ An example of this is sage-grouse.

- Does the wildlife species that will benefit from restoration have seasonal or annual home ranges larger than the size of a typical restoration project?

$\circ$ An example of this is sage-grouse.

- Do you have choices of locations where restoration will provide more benefit for your restoration investment?

- Sage-grouse populations will benefit more from restored habitat in Priority Areas for Conservation (PACs; U.S. Fish and Wildlife Service, 2013) than from restored habitat in the current sage-grouse range outside PACs. Restoration efforts that take place in either of these designated landscapes (PACs and current range) will benefit sage-grouse more relative to restoring areas outside the current range (fig. 1).
- Is the likelihood of restoration success greater in certain locations along spatial gradients of environmental variables?

- Resilience to disturbance increases with cooler soil temperature and with wetter soil moisture regimes. Revegetation successes also tend to increase along similar gradients. Because these gradients are spatially explicit, we can map and compare areas with high or low temperature and moisture regimes and thus expect a corresponding likelihood of restoration success (fig. 2; table 1).

- Are there natural or land use threats that may affect restoration success that can be spatially defined?

- Invasion of annual grasses can threaten the success of restoration projects. Risks of annual grass invasion can be portrayed spatially across a landscape similar to resilience gradients.

Similarly, anthropogenic development such as communication towers, highways, or powerlines also can influence the region's suitability to sage-grouse. The benefit from restoration projects conducted near these features can potentially be offset from increased predation.

- Are there specific locations in the landscape or region that potentially have a large influence on processes?

- Landscapes often contain locations within their configuration where topography, prevailing winds, or features such as existing habitat patches can significantly influence spatial flow of processes, such as fire spread or animal movements. 


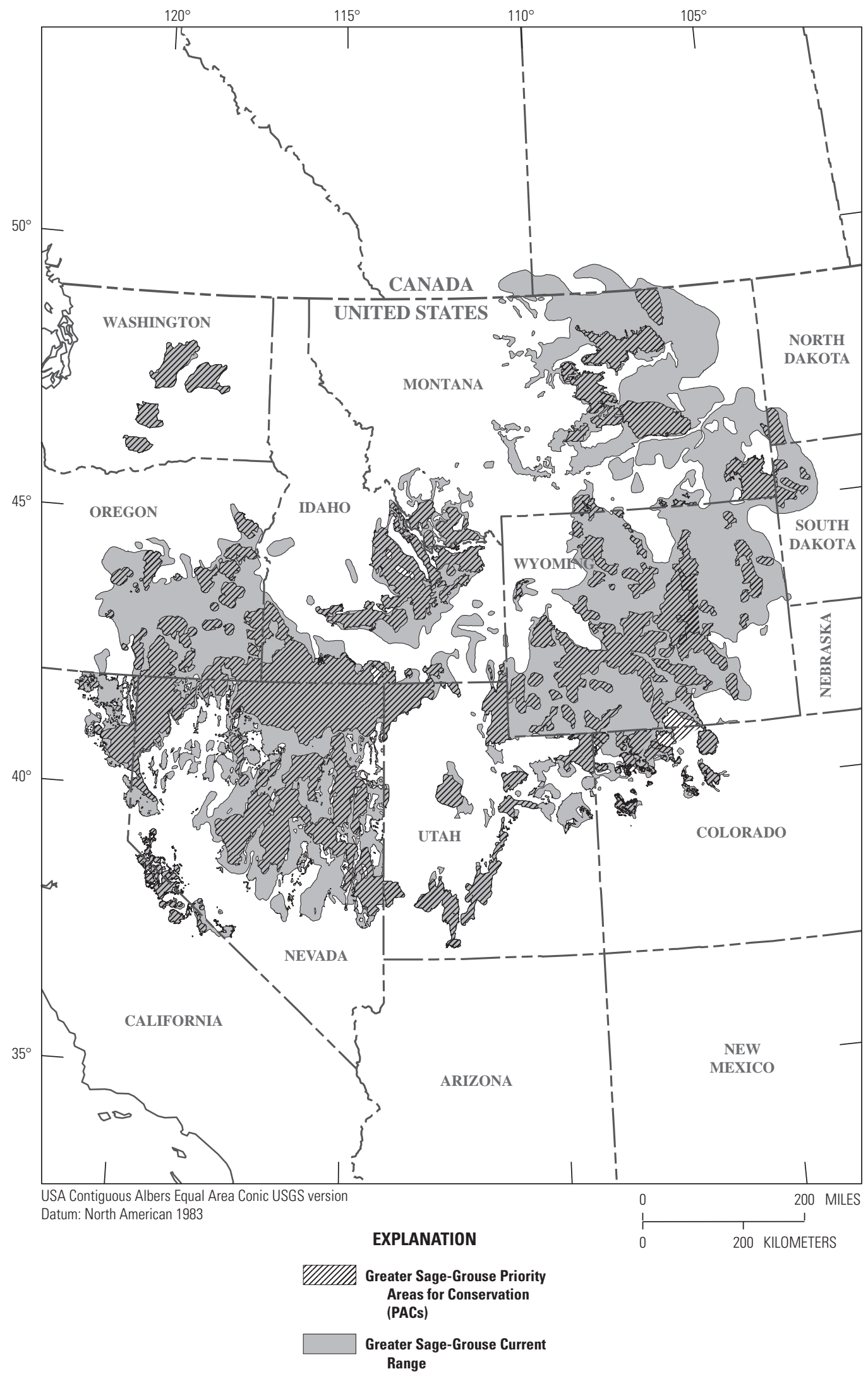

Figure 1. Greater sage-grouse Priority Areas for Conservation (PACs) within the current range of greater sage-grouse in the Western United States and Canada. Critical sagebrush habitats for most populations are included in the PACs. 


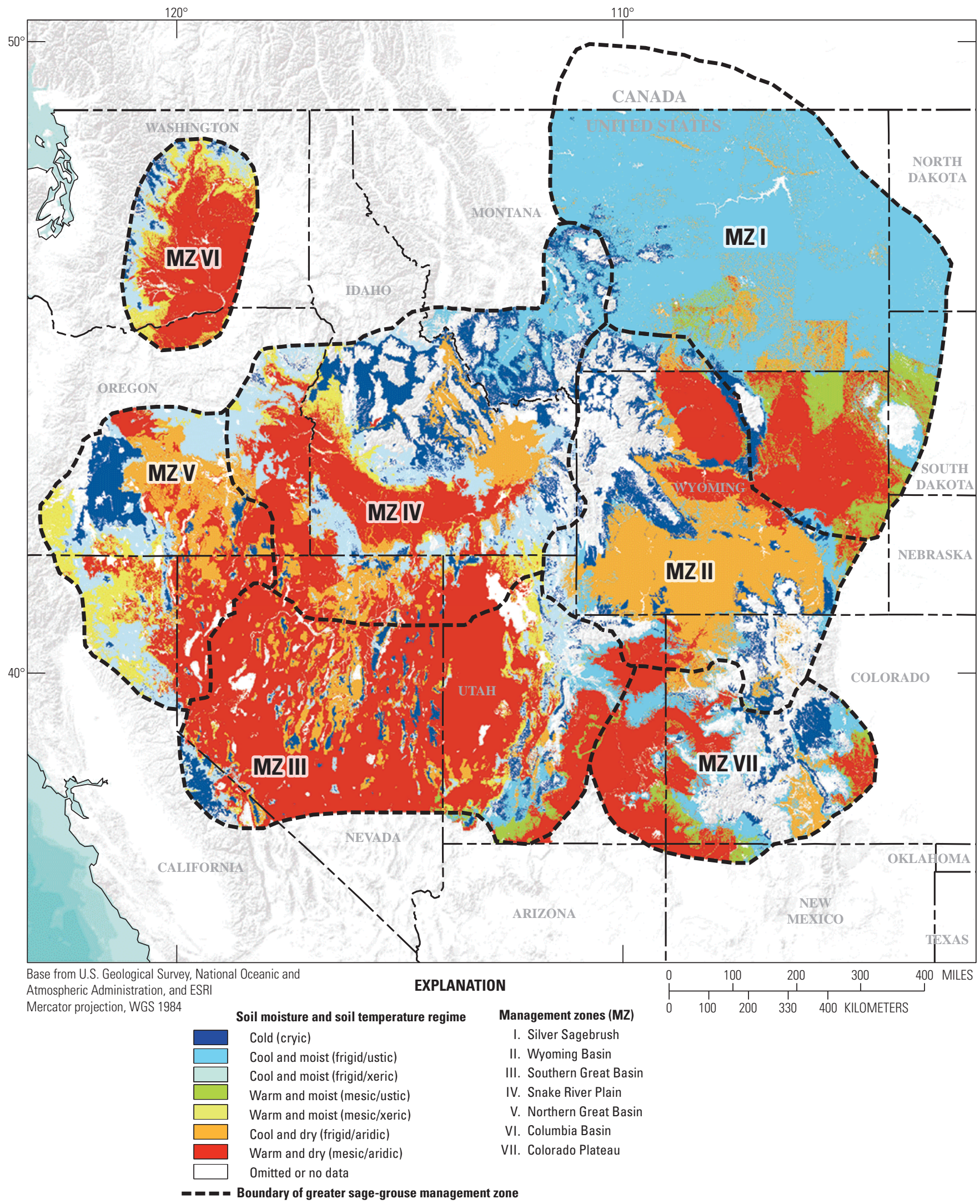

Figure 2. Soil temperature and moisture regimes that characterize the greater sage-grouse management zones (from Chambers and others, 2014). Management Zones (MZ) encompass the majority of sage-grouse in their floristic provinces (Pyke and others, 2015). 
Table 1. Major sagebrush ecological types in California, Idaho, Nevada, Oregon, Utah, and Washington.

[Sage-Grouse Management Zones III, IV, V, and VI based on soil temperature and soil moisture regimes (fig. 2), typical precipitation (Ppt) and shrubs, and resilience to disturbance and resistance to invasive annual grasses (modified from Chambers and others, 2014; Miller and others, 2014; Pyke and others, 2015). The Ustic soil moisture class is not included because data on resilience and resistance responses are lacking]

\begin{tabular}{|c|c|c|}
\hline Ecological type & Characteristics & Resilience, resistance, and restoration potential \\
\hline $\begin{array}{l}\text { Cool and moist } \\
\text { (frigid/xeric) }\end{array}$ & $\begin{array}{l}\text { Ppt: } 30-55 \text { centimeters (12-22 inches) } \\
\text { Typical shrubs: Mountain big sagebrush, } \\
\text { antelope bitterbrush, snowberry, and/or } \\
\text { low sagebrushes } \\
\text { Pinyon pine and juniper potential in some } \\
\text { areas }\end{array}$ & $\begin{array}{l}\text { Resilience - Moderately high. Precipitation and productivity are } \\
\text { generally high. Decreases in site productivity, herbaceous perennial } \\
\text { species, and ecological conditions can decrease resilience. } \\
\text { Resistance - Moderate. Climate suitability to invasive annual } \\
\text { grasses is moderate, but increase as soil temperatures increase. } \\
\text { Restoration - Moderately high - most years have adequate } \\
\text { precipitation for germination and establishment of seeded plants. }\end{array}$ \\
\hline $\begin{array}{l}\text { Cool and dry } \\
\text { (frigid/aridic) }\end{array}$ & $\begin{array}{l}\text { Ppt: } 15-30 \text { centimeters (6-12 inches) } \\
\text { Typical shrubs: Wyoming big sagebrush, black } \\
\text { sagebrush, and/or low sagebrushes }\end{array}$ & $\begin{array}{l}\text { Resilience - Low. Effective precipitation limits site productivity. } \\
\text { Decreases in site productivity, herbaceous perennial species, and } \\
\text { ecological conditions further decrease resilience. } \\
\text { Resistance - Moderate. Climate suitability to invasive annual } \\
\text { grasses is moderate, but increases as soil temperatures increase. } \\
\text { Restoration - Moderately low. Precipitation amount and annual } \\
\text { variability will likely limit germination in some years and invasive } \\
\text { annual grass competition will increase at the warmer end of the } \\
\text { gradient. }\end{array}$ \\
\hline $\begin{array}{l}\text { Warm and dry } \\
\text { (mesic/aridic, } \\
\text { bordering on } \\
\text { xeric) }\end{array}$ & $\begin{array}{l}\text { Ppt: } 20 \text {-30 centimeters (8-12 inches) } \\
\text { Typical shrubs: Wyoming big sagebrush, black } \\
\text { sagebrush, and/or low sagebrushes }\end{array}$ & $\begin{array}{l}\text { Resilience - Low. Effective precipitation limits site productivity. } \\
\text { Decreases in site productivity, herbaceous perennial species, and } \\
\text { ecological conditions further decrease resilience. Cool season } \\
\text { grasses susceptibility to grazing and fire, along with hot dry summer } \\
\text { fire conditions, promote cheatgrass establishment and persistence. } \\
\text { Resistance - Low. High climate suitability to cheatgrass and other } \\
\text { invasive annual grasses. Resistance generally decreases as soil } \\
\text { temperature increases, but establishment and growth are highly } \\
\text { dependent on precipitation. } \\
\text { Restoration - Low. Seedling germination and establishment is } \\
\text { difficult due to many years having insufficient moisture and due to } \\
\text { invasive annual grass competition. Transplants might provide an } \\
\text { alternative to seeds as the propagule of choice. }\end{array}$ \\
\hline
\end{tabular}




\section{Section 2. What Are Regional or Landscape Objectives for Restoration?}

The objective of landscape restoration is to create a pattern or mosaic from the arrangement of habitat patches that has a desired function. Landscape objectives can include restoring connectivity among existing but currently isolated habitat patches for wildlife by establishing habitat corridors to allow movement among populations. Another objective might focus on woodland reduction and sagebrush restoration in locations near sage-grouse leks or targeted towards critical seasonal habitats. include:

Examples of landscape objectives for restoration

- Increasing connectivity among priority regions, populations, seasonal habitats, or other vegetation or wildlife distributions.

- Developing an effective system of fire breaks for defending against habitat loss.

- Restoring diverse native plant communities as fuel reduction treatments to reduce the potential of large continuous wildfires.

- Establishing land cover buffers or zones to protect existing habitat patches for wildlife populations.

- If the objective is to maintain existing habitat, then management objectives of adjacent lands should be considered because they may threaten or become susceptible to threats that can influence the maintenance of the existing habitat. Adjacent lands also might represent a buffer that protects the interior habitat to disturbance.
It is important to consider the spatial and temporal context in which restoration efforts take place and consider multiple scales in setting objectives. Landscape objectives may differ depending on the spatial level of the landscape hierarchy. Each answer will differ in space and time dimensions of an expected treatment and response. Three differing perspectives at which objectives might be developed are shown in figure 3. Decisions made only within a single perspective without considering the hierarchical context could adversely affect priorities at other levels or may not benefit other scale objectives. For example:

- What regions are important within sagebrush steppe ecosystems?

$\circ$ Where in the Great Basin should we focus restoration efforts?

- Which ecoregions of the Great Basin are important for our objective?

- Which sites within ecoregions should we apply a treatment?

- How long and what variables should we measure for vegetation and wildlife response to our treatment at each of national, regional, and local levels?

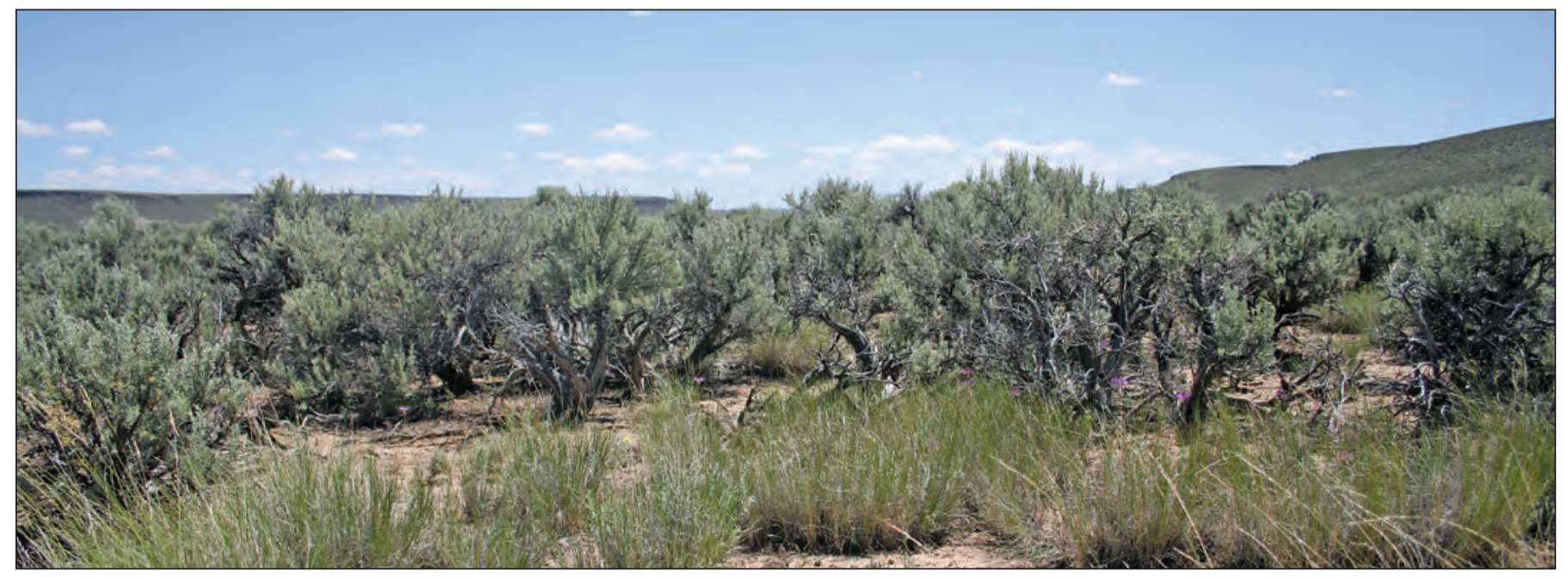

Bluebunch wheatgrass (Pseudoroegneria spicata) filling interspaces between Wyoming big sagebrush (Artemisia tridentata subsp. wyomingensis) near Burns, Oregon. Photograph by Michael Reisner, Augustana College, Illinois, June 29, 2009, used with permission. 


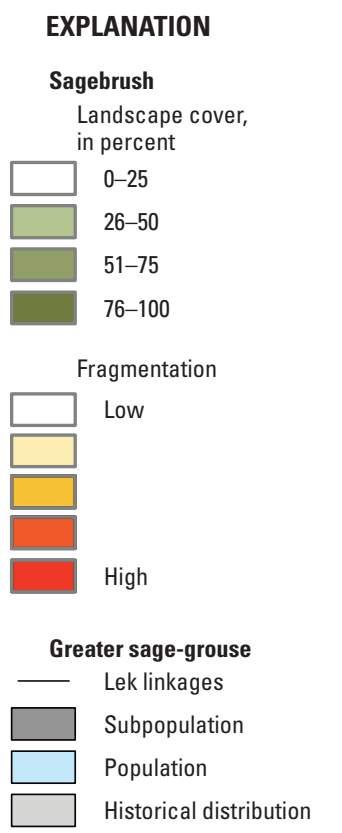

\section{National level}

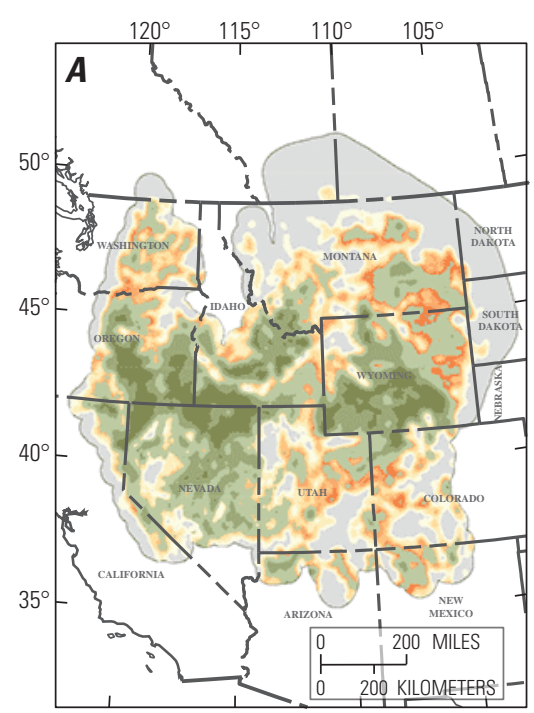

Regional level
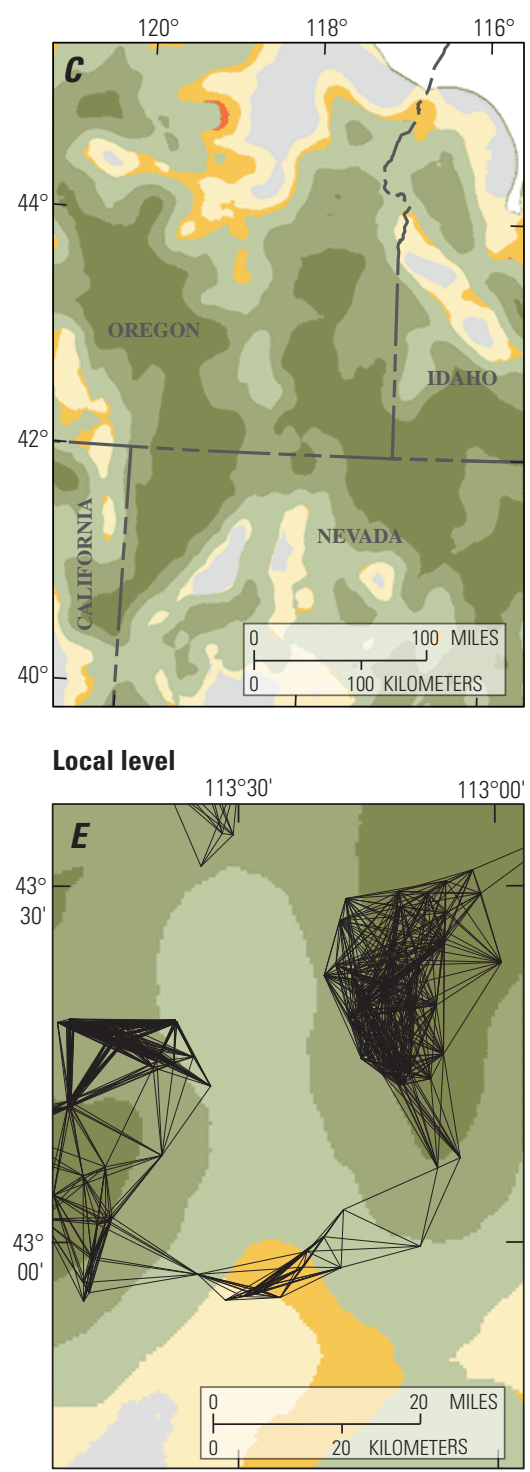
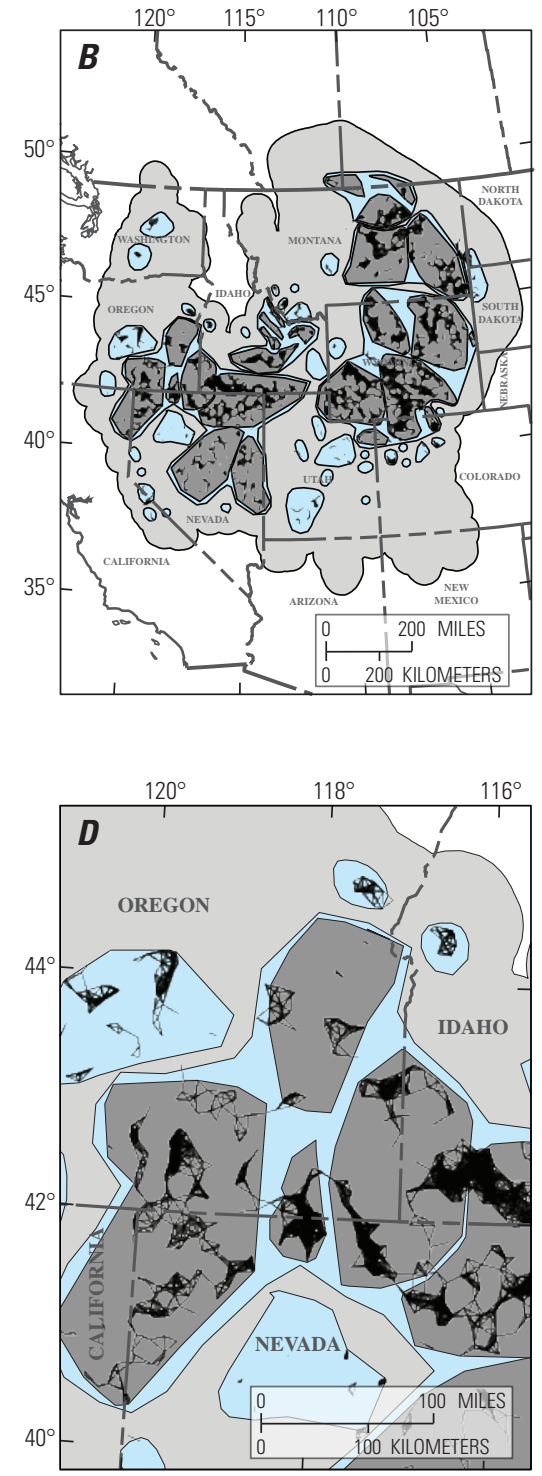

Figure 3. Three hierarchical scales in a decision process for identifying restoration actions. At a national level ( $A$ and $B$ ), priority decisions are made based on strongholds for greater sage-grouse and sagebrush within the range-wide distribution of the bird. At a regional level ( $C$ and $D$ ), patterns of habitat fragmentation and connectivity among populations or subpopulations are important considerations in locating potential restoration sites. At a local level $(E)$, actual restoration sites are identified to increase sagebrush area within a regional landscape and facilitate connectivity among individual breeding locations (leks) or seasonal use areas of greater sage-grouse. 


\section{Establishing Landscape Objectives Using SMART Protocol}

The most important consideration when developing a landscape restoration objective is a clear vision of the condition to which we want to restore the landscape. Restoring a landscape to some idealized ecosystem prior to pre-settlement by EuroAmericans is not possible. Similarly, the existing configuration of human and natural disturbances has largely changed where we might attempt landscape restoration. Past conditions and processes provide context and guidance for managing ecological systems today but may not be attainable. All objectives should follow the SMART protocol. SMART is an acronym for Specific, Measurable, Achievable, Reasonable, and Tractable, and can be applied when evaluating landscape restoration objectives. These objectives establish parameters for conducting effective restoration activities and implementing a successful monitoring plan.

- Specific and Measurable objectives require an explicit expected response that can be measured quantitatively with some degree of precision and certainty (Elzinga and others, 2001). At the landscape scale, this is often the amount and distribution of different land cover classes of dominant plants. Because landscape applications are most often designed to benefit wildlife populations, the expected response of wildlife populations would most likely be a stated objective that could be measured. Because of lag response periods within wildlife populations, any observed response might be difficult to assess without a commitment to long-term monitoring. These anticipated changes in landscape measurements will be in specific landscape patches (for example, State, field office, sage-grouse management zone or PAC) that could be directly linked to the restoration project.

- Achievable and Reasonable objectives incorporate two aspects. First, that planned projects have the potential to successfully change the amount and distribution of land cover within the landscape or to create a habitat condition that exceeds a threshold needed to elicit a response in the wildlife population. This ensures that anticipated restoration responses (for example, increased land cover of sagebrush or reduced fragmentation of existing sagebrush habitat) can actually be achieved. Second, the objective must stipulate a reasonable timeframe in which to accomplish the response. Thus, appropriate objectives will have timeframes for achievement and may reflect the hierarchical level within which the change can be observed. For example, site-specific objectives might anticipate a detectable trend towards the goal long before landscape metrics can be detected by satellite or other remote sensing platform. Increasing sagebrush cover across a dry and warm environment may take more than 40 years to detect.

- Tractable objectives provide assurances that objectives can be reasonably handled or accomplished. In terms of SMART objectives, tractability ensures that quantitative restrictions for meeting the objective are not so limited (Confidence Level or ground-truthing goals are unreasonably high or precision restricted too finely) such that it requires more effort to determine if the objective is met than can be reasonably accomplished.

- SMART Checklist for Landscape Objectives

○ Does the objective state an expected vegetation or animal response for a large spatial area or region?

- Examples include landscape cover (see Pyke and others, 2015, for definition relative to site-level cover), patch connections, or animal population trends.

○ Is that response measurable using an accepted quantitative method?

- The ability to measure landscape response will likely be limited to the availability of regional or rangewide maps of land cover or population estimates for animals within the landscape area. Complete "wallto-wall" coverage maps are produced in approximate 10-year intervals. Animal population trends may require similar or longer time intervals. However, local or regional maps and population estimates and updates may be available more frequently.

○ Does the objective state a time appropriate to achieve the stated restoration response?

- This is important for evaluating project effectiveness or success. Some landscape objectives, such as reducing juniper woodland cover near sage-grouse leks, might be accomplished within 1-2 years of treatment implementation. Other objectives, particularly those focused on restoration of sagebrush cover within a landscape or designed to increase the number of sage-grouse, may take decades before they are achieved. 


\section{Section 3. Where Are Priority Landscapes and Sites within Landscapes for Restoration?}

The process of prioritizing locations within the landscape for restoration actions involves three steps once the general landscape objective has been developed. Landscape objectives typically consist of multiple criteria or components that define the underlying reason for restoration, expected benefits, and factors that will influence the objective. Therefore, the first step is to identify the components or data layers that define parameters of the landscape objective. Data are then assembled as a set of spatial coverages or layers in a geographic information system (GIS). Last, data layers are then manipulated in GIS using a series of steps or by a mathematical function to identify potential sites that meet the set of criteria.

This filtering process can take place at multiple administrative or ecological levels (for example, fig. 3). However, the same basic concept of using a set of selection criteria to narrow the potential landscapes or locations for restoration is the same regardless of the hierarchical level although individual criteria will change. Consider the following questions for prioritizing landscapes across the 11 States of the sage-grouse range:

- Will restoration activities be implemented across the entire sage-grouse distribution or will some regions or locations (for example, some or all PACs or some populations) be given priority? The following are two examples of subdividing the entire sage-grouse range and prioritizing those subdivisions.

- Each State within the sage-grouse range has identified PACs (or equivalent priority areas) (fig. 1) within their boundaries. These PACs can be potential high priority locations for focusing restoration because they encompass sage-grouse population strongholds. Some PACs may be given higher priority for restoration when considering factors like current and planned land uses, climate change, and relative importance within the entire sage-grouse range.

○ Restoration may not be capable of providing sufficient habitat to stabilize or increase populations in all parts of the sage-grouse range. Restoration in certain landscapes will likely be more effective than others in achieving landscape objectives. For example, areas where populations are isolated on the fringe of the current distribution or stressed by land cover changes may have lower priority because the ecological change is too great or logistical cost of restoration will have little benefit relative to other areas. Similarly, regions along the more arid southern edge of the range might receive lower priority because climate change is likely to make long-term restoration of desired habitat improbable.

As the scale becomes smaller with these subdivisions, adapting a triage approach to focus restoration within population strongholds is important. Now consider the following question for prioritizing potential sites within landscapes:

- Will restoration be targeted on specific sage-grouse populations or directed towards seasonal use areas within priority landscapes?

$\circ$ Restoration might be focused on specific areas within the landscape surrounding leks that are important because of the population sizes they support or are in critical locations for maintaining connectivity among populations. Restoration actions at these sites, such as treatments to reduce woodland encroachment, are expected to benefit that individual lek or population.

\section{Process Step 1. Identify Individual Components or Data Layers That Define a Landscape Objective}

Consider the general landscape objectives used as examples in section 2, What Are Regional or Landscape Objectives for Restoration?, but now with the data layers that guide the objectives.

- Increasing connectivity among priority regions, populations, seasonal habitats, or other vegetation or wildlife distributions.

$\circ$ Planning for this restoration objective will require maps delineating existing land cover, potential for the land to support habitat (for example, use soil maps and their potential to support ecological sites), and identifying current populations of the targeted wildlife species so that potential locations for habitat restoration would increase connectivity.

- Developing an effective system of fire breaks for defending against habitat loss.

- Maps of fire probabilities and potential fire directions relative to existing habitat may aid in this objective. Existing access routes, such as roads or powerlines, also should be considered in planning the network of fuel breaks because these already exist and fragment habitat. Adding fuel breaks to these existing breaks in habitat would have less of an effect on quality habitat than fuel breaks through existing intact stands of sagebrush. 
- Restoring diverse native plant communities as fuel reduction treatments to reduce the potential of large wildfires.

- Maps of annual grass-dominated or tree encroachment areas relative to existing habitats may aid in prioritizing restoration. Restoring diverse plant communities can reduce invasive annual grasses and thus reduce fuel continuity. Similarly, removing trees changes fuel structure and aids in restoring sagebrush steppe.

- Are sagebrush ecosystems threatened by future fire, invasive species, and tree encroachment?

○ Fire risk maps may help in identifying areas that will likely be in high risk as opposed to low risk locations.

- Maps that predict current and potential dominance of invasive annual grasses or tree encroachment will likely identify areas with the potential for these invasives to dominate lands.

- Cheatgrass or downy brome (Bromus tectorum) is highly competitive with restoration seedlings, therefore low risk locations might be a better choice.

- Locations of current tree encroachment into sagebrush ecosystems threaten the dominance of sagebrush and provide potential perches for avian predators.

- How might climate change affect the desired habitat/ vegetation community?

○ If vegetation projection maps (for example, Still and Richardson, 2015) developed from climate change predictions are available, use them to establish boundaries of expected increases or decreases for vegetation communities and to help prioritize areas for restoration. For example, a warm, dry site at the southern margin of the vegetation range that is projected to get warmer and drier may have a lower priority to meet restoration objectives than a cool, moist site at the northern boundary of its current range under the same predictions. If vegetation projection maps are not available, then consider where habitat/ vegetation may be restricted by elevation, slope, or aspect for animals to migrate to favorable environments.
Process Step 2. Compile Spatial Data That Pertains to the Landscape Restoration Objectives You Are Trying to Achieve

- Where does the species of concern currently exist and what is the status of populations in each location?

- Spatial data for the current range of sage-grouse and for PACs (fig. 1) are available from State wildlife agencies. These were summarized initially by the Conservation Objectives Team (COT) report (U.S. Fish and Wildlife Service, 2013), but additional updates are made by individual States. For sage-grouse abundance, breeding bird density maps may aid this process (Doherty and others, 2010; fig. 4). Additionally, information on population trends would be useful. Contact State wildlife agencies for current information.

- Where does the landscape cover of desired vegetation/habitat occur?

- For sage-grouse, this would include landscape cover of sagebrush (fig. 5; see Pyke and others [2015] for an understanding of landscape cover of sagebrush). Landscape cover also includes native perennial grasses and forbs, but sagebrush is easily detected with remote sensing equipment and provides a surrogate for the community as a whole. In addition, sage-grouse population lek persistence is related to sagebrush landscape cover. Range-wide maps of sagebrush distribution are available from the SAGEMAP Website (http:// sagemap.wr.usgs.gov) or from the LandFire Existing Vegetation Type map of land cover (http://www.landfire.gov/viewer/). For other species, identifying relationships between home ranges and seasonal habitats may help define sizes of landscape patches that are important. In addition, information on population dispersal and genetic interchange may aid in identifying appropriate patch sizes. 


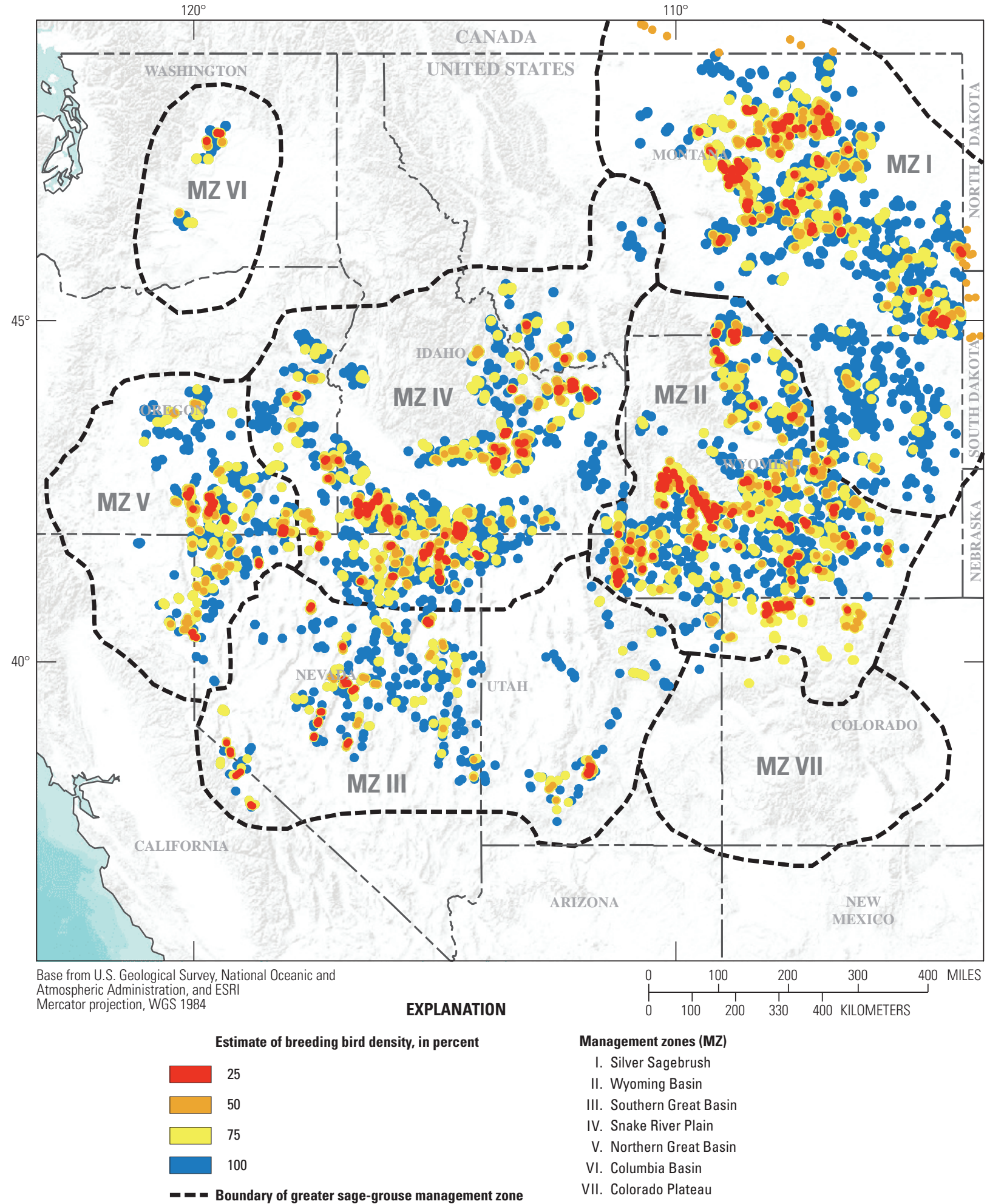

Figure 4. Estimates of breeding bird density of the greater sage-grouse (Doherty and others, 2010). Percentage of estimated breeding bird densities is based on the maximum counts at leks (breeding areas). 


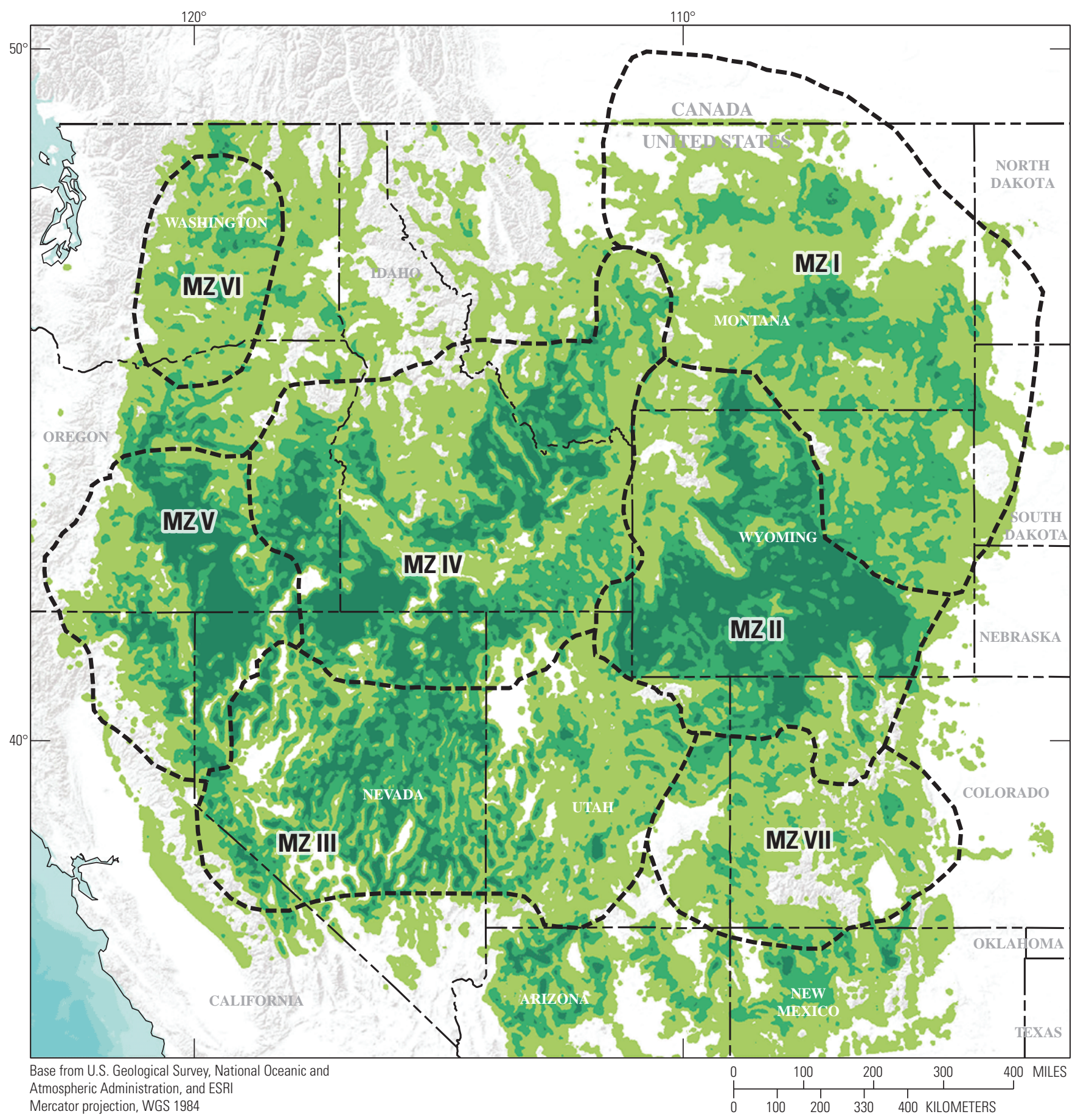

EXPLANATION
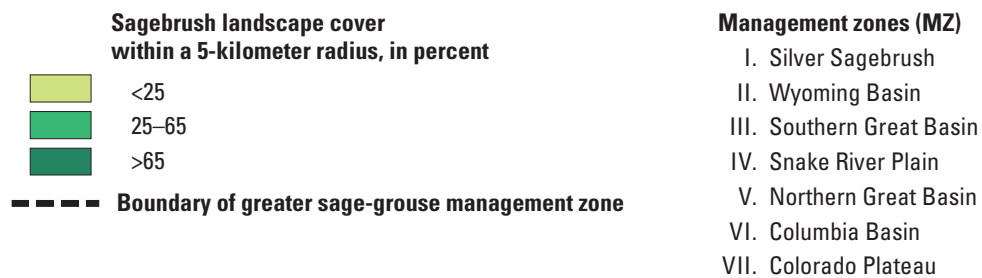

Figure 5. Landscape cover of sagebrush within each of the selected categories $(<25,25-65,>65$ percent $)$ for the greater sage-grouse management zones. Landscape cover of sagebrush was determined from remote sensing images of land cover. Locations within the range of greater sage-grouse where adjacent areas of a set size (5-kilometer radius) have similar amounts of sagebrush dominance were calculated and delineated in a geographic information system (GIS). See Chambers and others (2014) for details on the methods used to develop this map. 
- Where does the desired plant community have the potential to grow but is not currently dominant?

- The answer to this question will reveal where restoration, if successful, could enhance landscape restoration objectives. Maps of soil moisture and soil temperature regimes provide landscape patches consisting of a gradient of restoration potentials, resilience to disturbances, and resistance to invasive annual grasses (fig. 2; table 1). These maps may be accessed at Landscape Conservation Management and Analysis Portal https://www.sciencebase.gov/ catalog/folder/538e5aa9e4b09202b547e56c.

- Where are potential stressors that should be avoided to reduce their potential negative impact on achieving restoration objectives?

- Anthropogenic stressors-habitat fragmentation, pollution, introduction of exotic species, croplands, Interstate highways and roads, energy development (wells, wind towers), communication towers and transmission corridors, and urban development.

○ Natural stressors - extreme weather events such as prolonged drought or above average precipitation.
○ Natural covariates - prevailing climate, topography, streams, and wetlands.

- Maps of fire risk, human developments, transportation, pipeline, power, or communication corridors, energy development or mining sites that can be accessed at the SAGEMAP Website (http:// sagemap.wr.usgs.gov) as well as on many agency Web portals. Managers might consider buffering locations using results from (Manier and others, 2014) as a guide.

\section{Process Step 3. Identify a Set of Landscapes or Locations That Meet the Restoration Criteria}

The last step in the prioritization process uses a GIS to depict and manipulate spatial data and to delineate a smaller set of possible locations for site-specific restoration actions. The GIS forms multiple overlays where unions of layers may determine areas that meet all criteria. A series of if-then steps narrows the potential restoration sites with each criteria (see "Union of Layers"). The size and number of potential restoration sites becomes much smaller when the number of individual conditions are increased or as requirements for individual criteria become more specific.

\section{Union of Layers}

Recommended criteria for locating restoration sites to benefit raptors in the Snake River Birds of Prey National Conservation Area, southwestern Idaho, and developed at a workshop (Anonymous, 2000) on sagebrush steppe ecosystems include:

1. Identify and protect existing native habitat and restoration projects.

2. Give priority to restoration of sagebrush sites adjacent to existing sagebrush patches.

3. Limit restoration sites to less than $4.8 \mathrm{~km}$ of the north rim of the Snake River Canyon to benefit raptors nesting in the canyon.

4. Focus on areas with the greatest declines in raptor populations.

5. Develop connectivity among existing shrublands in the National Conservation Area.

6. Consider the gradient of site potentials, such as sites with higher precipitation and deeper soils, to improve potential for restoration success. 
More recent techniques have used statistical functions, such as similarity indices, to identify suitable locations based on a multivariate analysis of habitats (see "Mathematical Functions"). The statistical treatment of multiple variables permits assessments of tradeoffs among different combinations of variables.

\section{Mathematical Functions}

The western part of the sage-grouse range was prioritized for restoring sagebrush habitats (Meinke and others, 2009). The process illustrates the complexity that can be used by combining statistical models and GIS functions to prioritize the landscape.

1. Optimum conditions favorable for revegetation of sagebrush were delineated using a statistical model of elevation, precipitation, and soils specific to separate ecoregions.

2. The set of potential locations was then filtered by the objective to increase connectivity of existing sagebrush in a landscape. Fragmentation of sagebrush landscapes was based on a moving window of sagebrush land cover (see Pyke and others, 2015, p. 8, for explanation of moving window).

3. Restoration sites also needed to be within strongholds for sage-grouse populations derived from maps of sage-grouse leks.

4. The final set of restoration sites was developed by eliminating locations that had a significant potential impediment caused by cheatgrass invasion. Cheatgrass distribution was delineated from a statistical model of elevation, precipitation, and soils specific to separate ecoregions.

Managers were able to select restoration sites from among all potential restoration locations within their authority.

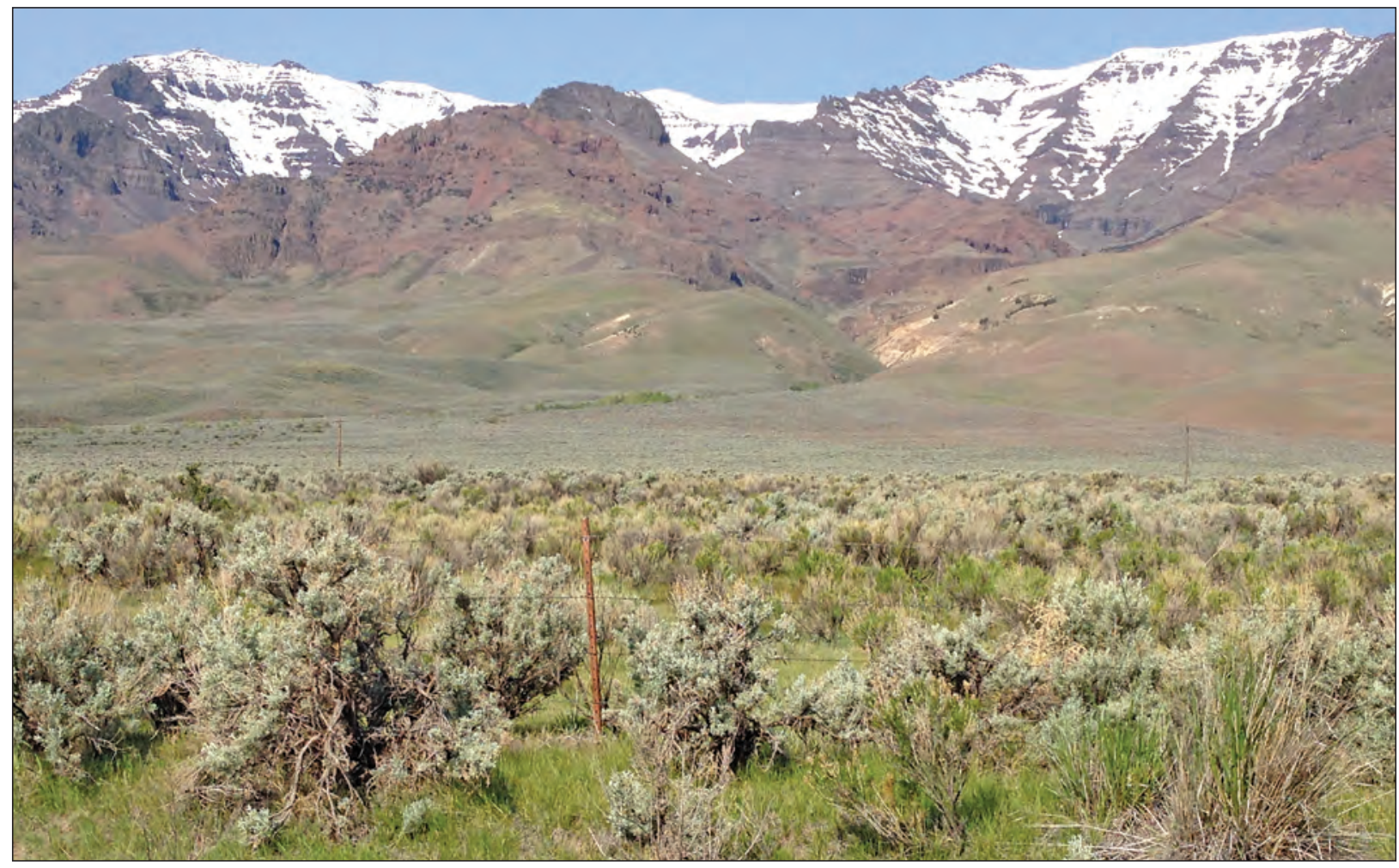

A Wyoming big sagebrush (Artemisia tridentata subsp. wyomingensis) stand with native perennial grasses on a warm dry site on the Denio-Fields Road, Oregon, looking toward the Steens Mountains. Photograph by David Pyke, U.S. Geological Survey, April 30, 2015. 


\section{Section 4. Prioritize Landscapes Using a Resilience and Resistance Matrix}

A Western Association of Fish and Wildlife Agencies workgroup has taken the triage concept and made revisions that relate directly to sage-grouse habitat needs and to resistance and resilience concepts for sagebrush ecosystems (table 2; Chambers and others, 2014; Pyke and others, 2015).

These concepts of resilience and resistance can be represented by spatial data to delineate regions and potential site locations where restoration might be focused. Process steps include:

1. Focus initially on sage-grouse population strong-holds by using the PACs within the potential range for the bird.

2. Determine the landscape cover of sagebrush using a moving window (5-km radius) approach and a rangewide classified image of sagebrush cover such as LANDFIRE (fig. 5).

3. Determine the soil temperature and soil moisture regimes (fig. 2).
4. Overlay these layers to determine the habitat matrix (table 2) landscape patches that can be used as potential restoration locations that will likely make the greatest contribution to sage-grouse habitat.

5. Identify areas with 25-65 percent cover and with intermediate to high levels of resilience/resistance as these areas will likely provide the greatest contribution to sage-grouse habitat (Chambers and others, 2014).

6. Use additional layers relating to location details such as breeding bird densities (fig. 4) may provide additional support for selecting locations for restoration.

Areas with greater than 65 percent landscape cover of sagebrush have a high probability of supporting persistent sage-grouse leks and are priority areas for sustaining high-quality habitat. Areas with $25-65$ percent landscape cover have an intermediate probability of supporting persistent sage-grouse leks with persistence increasing as the landscape cover of sagebrush increases. These areas are excellent locations for restoring habitat and creating corridors among existing high quality habitat as long as restoration is successful. Areas with less than 25 percent landscape cover are not likely to sustain viable sage-grouse leks.

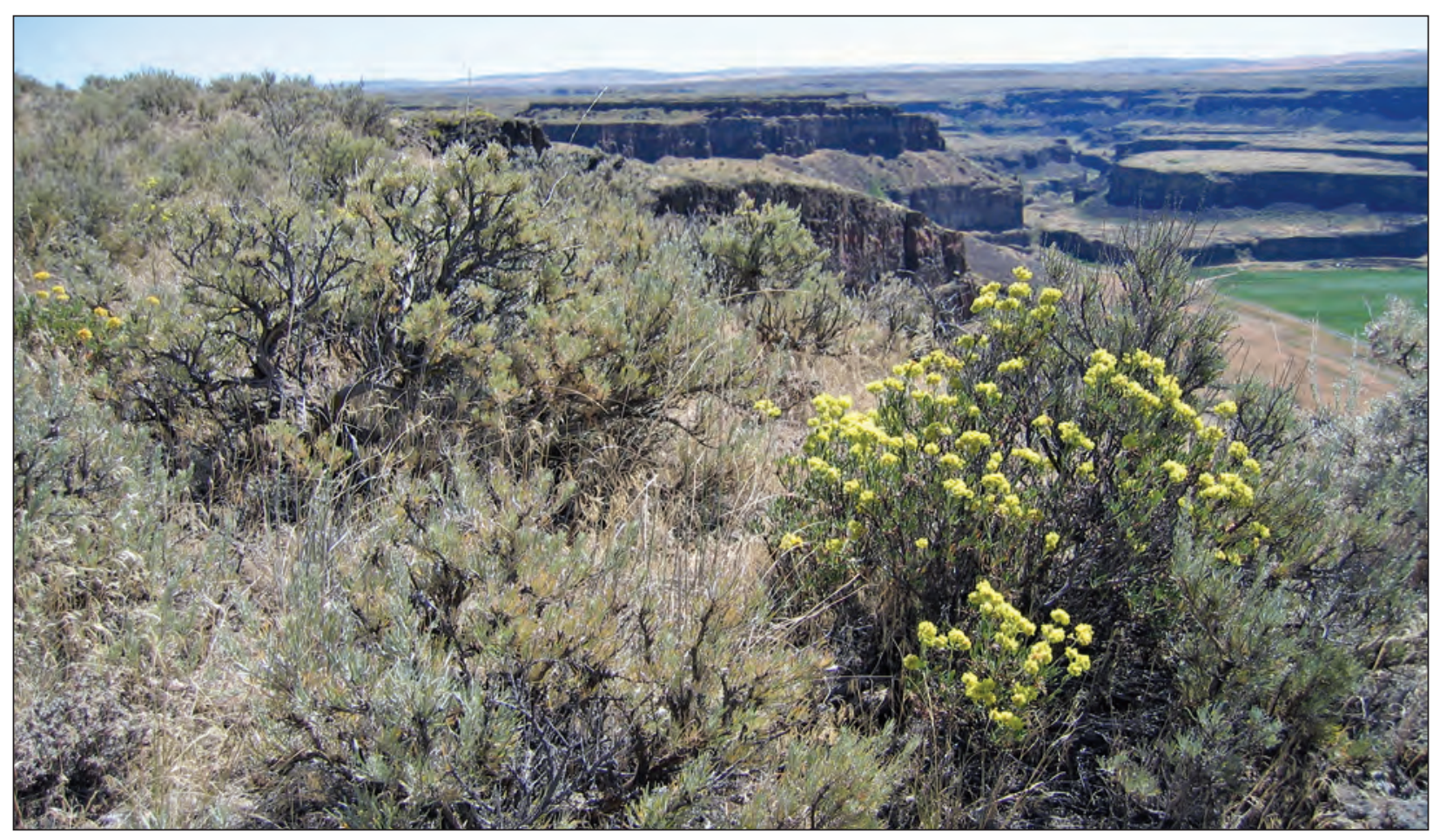

Wyoming big sagebrush (Artemisia tridentata ssp. wyomingensis) and bluebunch wheatgrass (Pseudoroegneria spicata) with buckwheat (Eriogonum sp.) flowering in the foreground over-looking Moses Coulee (east of Waterville, Washington). Photograph by David Pyke, U.S. Geological Survey, July 7, 2006. 
Table 2. Sage-grouse habitat matrix based on resilience and resistance concepts, and the proportional cover of the landscape dominated by sagebrush.

[From Chambers and others (2014). The habitat matrix combines landscape cover of sagebrush (fig. 5) with the resistance and resilience of the range of plant communities within the ecological types (table 1). Rows represent three of the generalized plant communities among the ecological types in table 1 with communities ranging from cold and moist $(1 \mathrm{~A}, 1 \mathrm{~B}, 1 \mathrm{C})$ to warm and dry $(3 \mathrm{~A}, 3 \mathrm{~B}, 3 \mathrm{C})$. Columns show the current proportion of the landscape $(5-k i l o m e t e r$ moving window) dominated by sagebrush (landscape cover of sagebrush, fig. 5). Rows in the matrix represent the probability of restoration or recovery which is associated closely with soil temperature and moisture regimes (fig. 2). The management goal is to move toward the right within a row; there is no movement between rows within a landscape or site]

\section{Proportion of landscape dominated by sagebrush}

\section{Low $<25$ percent}

Too little sagebrush on the landscape significantly threatens likelihood of sage-grouse lek persistence.

\section{$1 A$}

Natural sagebrush recovery is likely to occur, but the time required may be too great if large, contiguous areas lack sagebrush. Perennial herbaceous species are sufficient for recovery.

Risk of annual invasives is low.

Seeding/ transplanting success is high.

Appropriate livestock use is required.

\section{A}

Natural sagebrush recovery is likely to occur on cooler and moister sites, but the time required is too great if large, contiguous areas lack sagebrush. Perennial herbaceous species usually adequate for recovery on cooler and moister sites.

Risk of annual invasives is moderately high on warmer and drier sites.

Seeding-transplanting success depends on site characteristics, and more than one intervention may be required especially on warmer and drier sites.

Appropriate livestock use is required.

\section{$3 \mathrm{~A}$}

Natural sagebrush recovery is not likely. Perennial herbaceous species inadequate for recovery.

Risk of annual invasives is high.

3 Seeding-transplanting success depends on site characteristics, annual invasives, and post-treatment precipitation but is often low. More than one intervention likely will be required.

Appropriate livestock use is required.

\section{Moderate 25-65 percent}

Sage-grouse leks are sensitive to the amount of sagebrush remaining on the landscape and populations could be at-risk with additional disturbance that removes sagebrush.

\section{B}

Natural sagebrush recovery is likely to occur, but the time required may be too great if large, contiguous areas lack sagebrush. Perennial herbaceous species are sufficient for recovery.

Risk of annual invasives is low.

Seeding/ transplanting success is high.

Appropriate livestock use is required.

2B

Natural sagebrush recovery is likely to occur on cooler and moister sites, but the time required may be too great if large, contiguous areas lack sagebrush. Perennial herbaceous species usually adequate for recovery on cooler and moister sites.

Risk of annual invasives is moderately high on warmer and drier sites.

Seeding-transplanting success depends on site characteristics, and more than one intervention may be required especially on warmer and drier sites.

Appropriate livestock use is required.

\section{B}

Natural sagebrush recovery is not likely. Perennial herbaceous species inadequate for recovery.

Risk of annual invasives is high.

Seeding-transplanting success depends on site characteristics, annual invasives, and post-treatment precipitation but is often low. More than one intervention likely will be required.

Appropriate livestock use is required.

\section{High > 65 percent}

Sufficient sagebrush exists on the landscape and sage-grouse leks are highly likely to persist.

\section{C}

Natural sagebrush recovery is likely to occur. Perennial herbaceous species are sufficient for recovery.

Risk of annual invasives is low.

Seeding/ transplanting success is high.

Appropriate livestock use is required.

\section{C}

Natural sagebrush recovery is likely to occur on cooler and moister sites. Perennial herbaceous species usually adequate for recovery on cooler and moister sites.

Risk of annual invasives is moderately high on warmer and drier sites.

Seeding-transplanting success depends on site characteristics, and more than one intervention may be required especially on warmer and drier sites.

Appropriate livestock use is required.

\section{C}

Natural sagebrush recovery is not likely. Perennial herbaceous species inadequate for recovery.

Risk of annual invasives is high.

Seeding-transplanting success depends on site characteristics, annual invasives, and post-treatment precipitation but is often low. More than one intervention likely will be required.

Appropriate livestock use is required. 


\section{Section 5. Monitor and Report Information on Your Measurable Landscape Objectives}

Landscape objectives often encompass multiple scales of implementation and change, and monitoring programs should reflect those temporal and spatial extents. Desired features of a monitoring program to evaluate landscape objectives have similarities and differences when compared to site-specific monitoring. Landscape monitoring (adapted from Elzinga and others, 2001; Morrison, 2002) should include the following:

1. A concise, yet quantitative, description of the landscape monitoring objectives and the timeframe to achieve them are common to landscape and sitespecific objectives (see section 2, What Are Regional or Landscape Objectives for Restoration?)

2. Landscape areas that represent similar treated and untreated landscapes would be preferred. Areas may be randomly selected from among similar landscape areas. For a site-specific restoration objective, replicated treated and untreated areas are ideal, but this is difficult with larger landscapes and for areas with greater variation in landforms and disturbance histories.

3. Sampling before and after treatments allows for a determination of any differences that might occur between treated and untreated areas that were not due to landscape restoration treatments. These differences can then be accounted for and considered as treatment-related responses occur. Before and after treatment sampling is also important in site-specific monitoring.

4. Recognition and control of sources of bias that were not due to treatments, but may affect the responses, could be measured simultaneously.

Landscape treatments will likely require longer time intervals for observations than site-specific treatments because multiple site-specific restoration projects must be implemented before changes may be observed in landscape parameters. A suggested schedule for measuring landscape parameters might be to repeat monitoring every $3-5$ years. Once monitoring data are collected over multiple time intervals, then trends for landscape parameters and measures of the confidence in the direction of the trend might be determined. In addition, monitoring any potential losses of habitat not related to treatments will aid in determining if landscape restoration efforts can recover habitat at a rate that is greater than habitat loss from other factors (for example, fires).
When animal population levels are an important variable related to landscape restoration, then vital population numbers (for example, survival, emigration, and immigration) aid in understanding if landscape habitat objectives are being transformed into positive benefits in animal populations. If possible, these positive benefits should be reported within treated and untreated landscapes. Reports of these findings would assist managers in making adaptations to landscape restoration practices and goals in the future.

For example, removal of encroaching trees with mechanical techniques should achieve measurable habitat benefits in the short-term provided enough projects are strategically placed near active sage-grouse populations and sagebrush becomes dominant without trees surrounding the treatment locations. Achieving population goals for sage-grouse may require longer-term monitoring to detect positive change. However, a fire removing trees also will remove sagebrush and some perennial grasses, which will not likely achieve restoration goals nor benefit sage-grouse for possibly decades. In this example, monitoring the different components would include the following:

1. Monitor the extent and location of mechanical treatments.

2. Provide a baseline of the extent for restoration implementation actions.

3. Monitor landscape cover of sagebrush in priority landscape habitat.

4. Monitor any unplanned losses of landscape cover of sagebrush (for example, wildfire) that could negatively impact sage-grouse. Collectively the increase and loss of landscape cover of sagebrush help determine whether restoration is able to provide a net increase in habitat. If not, then restoration efforts will need to be either expedited or become more successful to achieve a net increase in habitat.

5. Monitor sage-grouse populations.

6. Use survey data at lek sites or, where feasible, telemetry methods near restoration sites to estimate if restoration influences changes in population growth rates and probability of occurrence, ultimately meeting landscape objectives related to sage-grouse. 


\section{Summary}

Landscape level restoration uses a hierarchical approach with objectives and decisions being made at different scales over time. Decisions made at any one scale may influence the effectiveness of meeting objectives at other scales. We have established a landscape restoration decision tool to lead decision-makers through the process of setting objectives and gathering appropriate data layers for prioritizing locations based on their perceived ability to achieve the objectives. This process ultimately leads to potential locations where site-specific restoration projects could be implemented to aid in achieving the objectives. Monitoring at the various scales will aid in determining the effectiveness of restoration in achieving the landscape objectives, but ample time must be given to allow multiple projects within a landscape patch to improve habitat conditions and quality and to allow wildlife populations to respond to landscape restoration actions.

\section{Acknowledgments}

This is Contribution Number 104 of the Sagebrush Steppe Treatment Evaluation Project (SageSTEP), funded by the U.S. Joint Fire Science Program (05-S-08), the National Interagency Fire Center, the Bureau of Land Management, the Great Northern Land Conservation Cooperative, and the U.S. Geological Survey. Additional funding was provided by the Western Association of Fish and Wildlife Agencies (WAFWA) through an agreement with Pheasants Forever and the Intermountain West Joint Venture under the Sage-Grouse Initiative Strategic Watershed Action Team (SGI SWAT). We thank members of the WAFWA Sage and Columbia Sharp-tail Grouse Technical Committee for their guidance and input on this project. We thank G. Chong, S. Beldin, P. Coates, and M. Ricca for reviews and input that improved this handbook.

\section{References Cited}

Anonymous, 2000, Snake River Birds of Prey NCA habitat restoration workshop summary and recommendations, in Entwistle, P.G., DeBolt, A.M., Kaltenecker, J.H., and Steenhof, K., compilers, Proceedings of the sagebrush steppe ecosystem symposium: Boise, Idaho, Bureau of Land Management Publication No. BLM/ID/PT-001001+1150, p. 133-142.
Chambers, J.C., Pyke, D.A., Maestas, J.D., Pellant, M., Boyd, C.S., Campbell, S., Espinoza, S., Havelina, D., Meyer, K.E., and Wuenschel, A., 2014, Using resistance and resilience concepts to reduce impacts of invasive annual grasses and altered fire regimes on the sagebrush ecosystem and sagegrouse-A strategic multi-scale approach: Fort Collins, Colorado, U.S. Department of Agriculture, Forest Service, Rocky Mountain Research Station, RMRS-GTR-326, 73 p.

Doherty, K.E., Tack, J.D., Evans, J.S., and Naugle, D.E., 2010, Mapping breeding densities of greater sage-grouse-A tool for range-wide conservation planning: U.S. Department of the Interior, Bureau of Land Management, Completion report, Agreement \#L10PG00911, accessed December 9, 2014, at http://www.blm.gov/pgdata/etc/medialib/blm/wo/ Planning_and_Renewable_Resources/fish_wildlife_and/ sage-grouse.Par.6386.File.dat/MOU\%20on $\% 20$ Greater $\% 20$ Sage-Grouse.pdf.

Elzinga, C.L., Salzer, D.W., Willoughby, J.W., and Gibbs, J.P., 2001, Monitoring plant and animal populations: Malden, Massachusetts, Blackwell Science, 360 p.

Manier, D.J., Bowen, Z.H., Brooks, M.L., Casazza, M.L., Coates, P.S., Deibert, P.A., Hanser, S.E., and Johnson, D.H., 2014, Conservation buffer distance estimates for Greater Sage-Grouse-A review: U.S. Geological Survey OpenFile Report 2014-1239, 14 p., http://dx.doi.org/10.3133/ ofr20141239.

Meinke, C.W., Knick, S.T., and Pyke, D.A., 2009, A spatial model to prioritize sagebrush landscapes in the intermountain west (U.S.A.) for prioritization: Restoration Ecology, v. 17, p. 652-659.

Miller, R.F., Chambers, J.C., and Pellant, M., 2014, A field guide to selecting the most appropriate treatments in sagebrush and pinyon-juniper ecosystems in the Great Basin-Evaluating resilience to disturbance and resistance to invasive annual grasses and predicting vegetation response: Fort Collins, Colorado, U.S. Department of Agriculture, Forest Service, Rocky Mountain Research Station, RMRS-GTR-322, 66 p.

Morrison, M.L., 2002, Wildlife restoration-Techniques for habitat analysis and animal monitoring: Washington, D.C., Island Press, 209 p.

Noss, R.F., LaRoe, III, E.T., and Scott, J.M., 1995, Endangered ecosystems of the United States: a preliminary assessment of loss and degradation: Washington, D.C., U.S. Department of the Interior, National Biological Service, Biological Report 28, 58 p. 
Pyke, D.A., Chambers, J.C., Pellant, M., Knick, S.T., Miller, R.F., Beck, J.L., Doescher, P.S., Schupp, E.W., Roundy, B.A., Brunson, M., and McIver, J.D., 2015, Restoration handbook for sagebrush steppe ecosystems with special emphasis on greater sage-grouse habitat-Part 1. Concepts for understanding and applying restoration: U.S. Geological Survey Circular 1416, 44 p., http://dx.doi.org/10.3133/ cir1416.

Still, S.M., and Richardson, B.A., 2015, Projections of contemporary and future climate niche for Wyoming big sagebrush (Artemisia tridentata subsp. wyomingensis) - $\mathrm{A}$ guide for restoration: Natural Areas Journal, v. 35, no. 1, p. 30-43.
U.S. Fish and Wildlife Service, 2013, Greater Sage-grouse (Centrocercus urophasianus) conservation objectivesFinal Report: Denver, Colorado, U.S. Department of the Interior, Fish and Wildlife Service, 91 p.

U.S. Fish and Wildlife Service, 2015, Endangered and threatened wildlife and plants - 12-month finding on a petition to list Greater Sage-Grouse (Centrocercus urophasianus) as an endangered or threatened species: Federal Register, v. 80, p. 59,857-59,942, accessed October 8, 2015, at https://federalregister.gov/a/2015-24292. 

Publishing support provided by the U.S. Geological Survey Science Publishing Network, Tacoma Publishing Service Center

For more information concerning the research in this report, contact the Director, Forest and Rangeland Ecosystem Science Center U.S. Geological Survey

777 NW 9th St., Suite 400

Corvallis, Oregon 97330

http://fresc.usgs.gov 
